EREM 72/4

Journal of Environmental Research, Engineering and Management Vol. 72 / No. 4 / 2016

pp. 8-16

DOI 10.5755/j01.erem.72.4.16555

(c) Kaunas University of Technology
Toxicological Assessment of Closed Municipal Solid-waste Landfill Impact on the Environment

\title{
Toxicological Assessment of Closed Municipal Solid-waste Landfill Impact on the Environment
}

\author{
Jūratė Žaltauskaitė, Iveta Vaitonytė \\ Vytautas Magnus University, Department of Environmental Science, Faculty of Natural Sciences \\ Vileikos st. 8, LT-44404, Kaunas, Lithuania
}

Corresponding author: jurate.zaltauskaite@vdu.lt

J. Žaltauskaitè, Vytautas Magnus University, Department of Environmental Science, Faculty of Natural Sciences

Vileikos st. 8, LT-44404, Kaunas, Lithuania

A large number of municipal solid waste landfills in Lithuania pose a serious environmental threat to the quality of soil, surface and ground water. The physicochemical characteristics and toxicity of closed Panevežys municipal solid-waste landfill leachate and its impact on soil and surface water were assessed. Landfill leachate is a complex mixture of various inorganic and organic compounds. The toxicity of municipal solid waste landfill leachate and surface water was evaluated using bioassays with aquatic plants (Lemna minor L.) and micro-invertebrates (Daphnia magna). The leachate was shown to be toxic to $D$. magna, and it also reduced the growth and biomass of $L$. minor. The toxicity has been linked with ammonium and heavy metal content as the prime contributors to the toxicity.

Keywords: landfill leachate, Lemna minor, Daphnia magna, toxicity.

\section{Introduction}

Landfills are of great environmental importance in Lithuania, which currently disposes approximately $80 \%$ of its waste in landfill sites. Landfilling accounts for more than 70\% of waste treatment in Lithuania (Eurostat, 2014). Municipal landfills are the sources of a wide range of chemicals and may pose ecological and human health risks. The chemicals are released into the environment in the form of leachate, gas and particulate matter.

Landfills affect soil quality in the surroundings, and usually increased concentrations of chlorides, sulphates, nitrates and heavy metals are detected in the vicinity of a landfill (Hernández et al., 1998). However, the ma- 
jor potential environmental threat related to landfills is leachate. The exposure of landfill leachate to environment and biota may occur in different ways, such as uncontrolled overflow, rainfall run-off and infiltration.

Leachate is generated by percolation of precipitation and moisture through waste layers in a landfill. Landfill leachate is a complex mixture containing dissolved organic matter, inorganic macro-components, heavy metals and xenobiotic organic compounds (Kjeldsen et al., 2002). Moreover, landfill leachate is a source of new and emerging pollutants, such as perfluorinated compounds, alkylphosphates, personal care products and pharmaceuticals (Eggen et al., 2010).

The composition of leachate is highly variable and depends on numerous factors, such as age of a landfill, degree of solid waste stabilisation, solid waste characteristics, composition of waste, size of a hill, moisture and degree of rainwater infiltration, temperature and landfill geometry. Since it is a complex and highly variable composition, the hazard assessment of leachate is difficult. Traditionally, landfill leachate hazard assessment has been based on the physicochemical parameters, e.g., biological oxygen demand (BOD), pH, chemical oxygen demand (COD) and total dissolved solids. However, these parameters do not give an indication on the toxic potential of leachate to biota. Moreover, the majority of chemicals in leachate are not subject of routine monitoring and, therefore, biological effects resulting from the exposure of a living organism to these numerous pollutants may be underestimated. Toxicity bioassays integrate the biological effects of all compounds present in leachate and other factors, such as bioavailability, toxicant interaction and others. Toxicity bioassay, using species that represent different trophic levels, is the best approach to evaluate the toxicity of leachate. The impact of leachate on living organisms is very high and governed by several factors, such as high load of organic compounds, high content of ammonium, alkalinity and heavy metals (Thomas et al., 2009).

The majority of old Lithuanian landfills were built without engineered liners and leachate collection and treatment systems. To implement EU Landfill Directive (Council Directive 1999/31/EC), Lithuania has closed old, unsafe and/or small landfills and only those meeting the EU requirements have remained in operation or new, modern engineered landfills have been implemented.
Closed landfills require post-closure maintenance, and a period of at least 30 years of aftercare is specified in 1999/31/EC. Aftercare management of closed landfills typically includes monitoring of emissions and environmental quality (air, soil, surface water and groundwater), maintenance of the final cover and collection systems of leachate and gas (Sizirici et al., 2011, Laner et al., 2012). The main aim of this paper was to determine the impact of Panevéžys municipal solid waste (MSW) landfill leachate on the soil and surface water quality and toxicity to aquatic macrophyte Lemna minor and micro-invertebrate Daphnia magna.

\section{Materials and methods}

\section{Sampling site characteristics}

Panevežys municipal solid waste (MSW) landfill is situated in the north-eastern part of Lithuania $\left(55^{\circ}\right.$ $\left.42^{\prime} 7.82^{\prime \prime}, 24^{\circ} 29^{\prime} 16.36^{\prime \prime}\right)$. The landfill is situated $8 \mathrm{~km}$ southeast from Panevèžys city centre. Panevèžys MSW landfill was established in 1975 and closed in 2009. The area of the landfill is $52.53 \mathrm{ha}$. During the operation, the landfill received more than 1.5 million $\mathrm{m}^{3}$ of municipal and non-hazardous industrial wastes. The mean annual temperature at the study site is $6.5^{\circ} \mathrm{C}$, and the mean precipitation amount is approximately $650 \mathrm{~mm} \mathrm{y}^{-1}$.

The samples of the soil, the leachate and the surface water were collected in November, 2015. The leachate was sampled from a landfill leachate storage reservoir. The samples of the leachate and the surface water were collected in $2 \mathrm{~L}$ flasks and transported to the laboratory. Filtered $(0.45 \mu \mathrm{m})$ (for chemical analysis) and non-filtered samples (for bioassays) were stored in a refrigerator prior to performance of chemical analysis and bioassays.

In order to determine the impact of the landfill on the surface water quality, the surface water samples were collected from Aulamas stream flowing through the landfill. Aulamas stream water samples were collected from 2 sampling sites: upstream (HP2) and downstream (HP1) of the landfill.

The soil samples were taken from the topsoil layer $(0-15 \mathrm{~cm})$ within a $25 \mathrm{~m}$ radius of the landfill waste dumping site. In the laboratory, the soil samples were dried, 
ground and sieved prior to chemical analysis. The soil samples were dried for $48 \mathrm{~h}$ at $70^{\circ} \mathrm{C}$ temperature in an oven. Soil $\mathrm{pH}_{\mathrm{H} 2 \mathrm{O}}$ was detected potentiometrically. The soil samples for heavy metal analysis were digested using the Milestone Ethos One closed-vessel microwave system.

For the quantitative determination of metals $(\mathrm{Cu}, \mathrm{Cd}, \mathrm{Ni}$, $\mathrm{Pb}$ ) in the soil and the leachate, a Shimadzu AA-6800 atomic absorption spectrometer was used. All the reagents were of the analytical reagent grade. Analysis of anions and cations in the water was performed by ion chromatography with conductivity detection (Dionex 1100). pH was measured potentiometrically. Concentrations of ammonia $\left(\mathrm{NH}_{3}\right)$ were estimated from the measured concentrations of ammonium $\left(\mathrm{NH}_{4}^{+}\right)$and taking into account a Kb of $1.8 \times 10^{-5}$ (Pablos et al., 2011).

$$
N H_{3}=N H_{4}^{+} \times 10^{(p H-14)} / 1.8 \times 10^{-5}
$$

\section{Toxicity assessment}

The leachate and surface water toxicity assessment was conducted using micro-invertebrates Daphnia magna and aquatic macrophytes common duckweed (Lemna minor L.). The standardised growth inhibition test with common duckweed Lemna minor was performed according to OECD Guideline 221 (OECD 2004). The stock culture of $L$. minor was grown in modified Steinberg medium (ISO/DIS20079) in growth chambers at $24^{\circ} \mathrm{C} \pm 2^{\circ} \mathrm{C}$ with a light/dark cycle of $16 / 8 \mathrm{~h}$. Ten double-fronded healthy $L$. minor colonies were transferred to Petri dishes containing different concentrations of the leachate $(100 \%, 50 \%, 25 \%, 12.5 \%, 6.25 \%, 3.125 \%)$, the surface water (Aulamas stream) and the control. The dilutions of the leachates were made with the control Steinberg growth medium. The assays were performed in 3 replicates per treatment and lasted 7 days.

The toxicity was recorded as percent inhibition of growth (fronds number and biomass) (relative to control) of L. minor as a result of 7-day exposure. The specific growth rate was calculated from the following equation with fronds number at the end $\left(\mathrm{N}_{\mathrm{t} 1}\right)$ and the start of the test $\left(\mathrm{N}_{\mathrm{t}}\right)$ :

$$
r=\frac{\ln \left(N_{t_{1}}\right)-\ln \left(N_{t_{0}}\right)}{t_{1}-t_{0}}
$$

The acute 24-48 h Daphnia magna immobilisation test was performed according to OECD Guideline 202 (1984). The control was the growth medium of $D$. magna. Five organisms (less than $24 \mathrm{~h}$ old) were exposed to each dilution sample in 3 replicates. After 24-h and 48-h incubation in the light/dark cycle $16 / 8 \mathrm{~h}$ at $20 \pm 1^{\circ} \mathrm{C}$, the number of immobilised individuals was recorded.

The results of the toxicity tests were expressed as the concentration of the sample that produced a $50 \%$ effect (e.g., growth inhibition or mortality) $\left(\mathrm{EC}_{50}\right.$ or $\left.\mathrm{LC}_{50}\right)$. $\mathrm{EC}_{50}$ $\left(\mathrm{LC}_{50}\right)$ values were expressed as a percentage of the leachate tested. The toxicity values were converted to toxic units (TU), i.e., inverse of $\mathrm{EC}_{50}\left(\mathrm{LC}_{50}\right)$ expressed in \%:

$$
T U=\frac{1}{E C_{50}} \times 100
$$

The toxicity classification is reported as follows (Persoone et al., 2003): TU $<0.4$ - no acute toxicity; $0.4<\mathrm{TU}<1$ - slight acute toxicity; $1 \leq \mathrm{TU}<10$ - acute toxicity; $10 \leq \mathrm{TU}<100$ - high acute toxicity; $\geq$ TU 100 very high acute toxicity.

A one-way analysis of variance (ANOVA) was used to assess the leachate concentration and the surface water effect on the estimated end points. Significant differences between the control and the treatment samples were determined by the Dunnett test, and $p<0.05$ was considered to be significant. Significant differences between the treatments were determined by the Student test, and $p<0.05$ was considered to be significant. The statistical analysis was carried out using Statistica software.

\section{Results and discussion}

\section{Chemical characteristics of leachate and surface water}

Chemical characteristics of Panevėžys MSW landfill leachate and Aulamas stream water are presented in Table 1. Generally, in the analysis of MSW landfill leachates' chemistry, the focus is on the concentrations of nutrients, especially nitrogen. The concentration of nitrates in the leachate met the Lithuanian legislative 
limits for nitrates in the leachate (Standards for effluent quality, 1996). The concentrations of ammonium exceeded the permitted limits by 47.9 times. The ammonia (ionized $\mathrm{NH}_{4}^{+}$and un-ionized $\mathrm{NH}_{3}$ ) content in leachates, wastewaters and surface waters has previously been shown to explain a significant amount of toxicity to plants and invertebrates (Clément et al., 1997, Ward et al., 2002, Svensson et al., 2005, Žaltauskaite and Čypaitè, 2008, Thomas et al., 2009). Long-term studies indicate that the concentration of ammonia in leachate does not decrease with time, and it often constitutes a major long-term pollutant in leachate even after the closure (Kjeldsen et al., 2002).

Analysis of the heavy metal concentrations in the leachate revealed that $\mathrm{Pb}$ was the most abundant metal in the leachate and the other metals were ranked in decreasing order $\mathrm{Pb}>\mathrm{Ni}>\mathrm{Cu}>\mathrm{Cd}$ (Table 1). The heavy metal concentrations in the leachate exceeded the legislation limits. High heavy metal levels could be partially explained by the fact that both household and industrial waste was disposed during the operation in Panevezžys MSW landfill.

Such leachate chemistry parameters are typical of the leachate of municipal landfills, and the concentrations of pollutants were in the same order as those measured in the leachates from other landfills in Lithuania (Jaskelevičius and Lynikienè, 2009, Svecevičius et al., 2013).

The impact of the landfill leachate on the quality of stream water was observed. The concentrations of oxidised and reduced nitrogen in the samples collected downstream the landfill were higher than in the samples collected upstream the landfill (Table 1). The concentrations of ammonium in Aulamas stream water exceeded the permitted levels both upstream (3.64 times) and downstream (4.06 times) the landfill. The elevated nutrient concentrations have also been found in groundwater and surface waters in the municipal solid waste landfill area in Lapes (Juodkazis and Urbanavičiūtè, 2002, Česonienè and Lukenskienè, 2006). An increased heavy metal content has been recorded in the stream flowing through Gdansk landfill (Poland) (Melnyk et al., 2014).

The concentrations of heavy metals in the soil collected in the vicinity of the landfill were detected in a wide range (Figure 1). The concentrations of $\mathrm{Cu}$ and $\mathrm{Pb}$ exceeded the Lithuanian legislation limits (Order for approval of the requirements for chemicals, 2008) by twofold, and

\begin{tabular}{|l|c|c|c|c|c|c|c|c}
\hline & NO3--N & NH4+-N & $\mathrm{NH3}^{*}$ & $\mathrm{pH}$ & $\mathrm{Cu}$ & $\mathrm{Pb}$ & $\mathrm{Cd}$ & $\mathrm{Ni}$ \\
\hline \multicolumn{1}{c|}{1} & 2 & 3 & 4 & 5 & 6 & 7 & 8 & 9 \\
\hline Leachate & 8.35 & 719.16 & 513.68 & 9.00 & 2.65 & 4.00 & 0.40 & 3.03 \\
\hline Surface water HP2 & 0.03 & 2.84 & 0.075 & 7.57 & N.A. ${ }^{* *}$ & N.A. & N.A. & N.A. \\
\hline Surface water HP1 & 0.06 & 3.17 & 0.082 & 7.56 & N.A. & N.A. & N.A. & N.A. \\
\hline
\end{tabular}

Table 1

Chemical characteristics of landfill leachate (mg L-1) and surface water (Aulamas stream)

* concentration estimated from measured $\mathrm{pH}$ and $\mathrm{NH} 4+$ values

${ }^{* *}$ N.A. not analysed

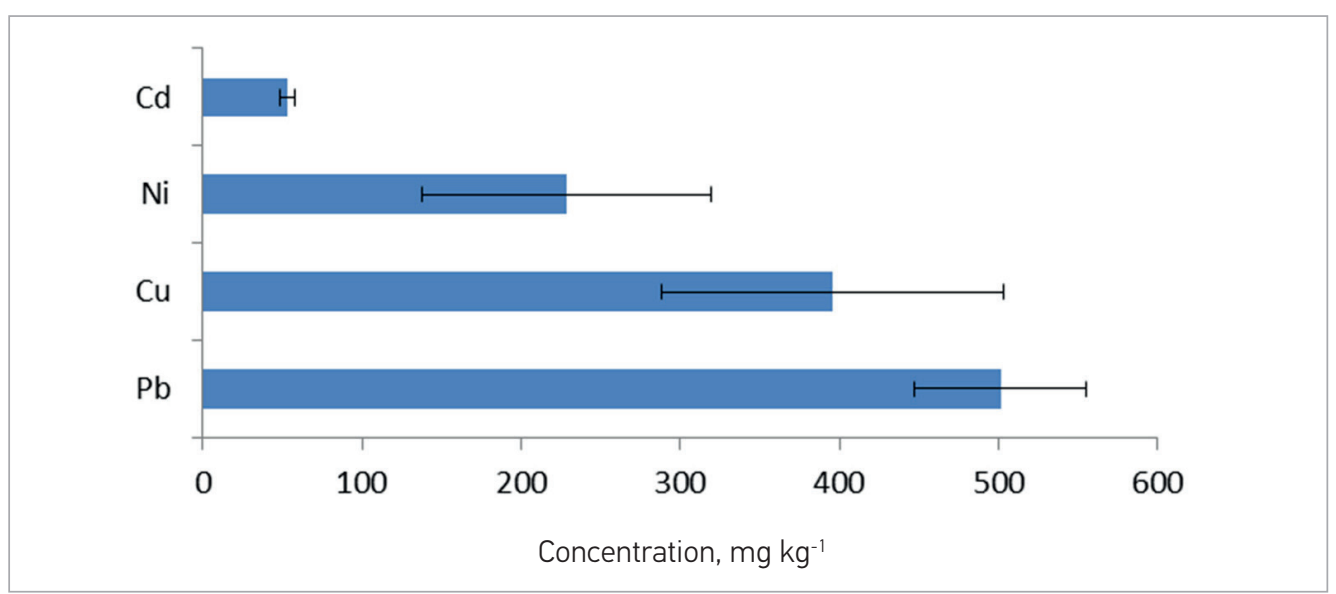

Fig. 1

Heavy metal soil concentrations $\left(\mathrm{mg} \mathrm{kg}^{-1}\right)$ in Panevežys MSW landfill 
Cd by up to 17.7 times. No significant relationship was found between heavy metal soil concentration and distance from the waste dumping site. After leachate application on the vegetated landfill cover in Ottawa County (Michigan), a trend toward gradually increasing metal concentrations in the leachate irrigated plots has been observed (MacDonald et al., 2008). Calace et al. (2001) have pointed out that landfill leachate application led to an increased capacity to retain heavy metals. Chemical analysis of soils and waters in the vicinity of 15 closed solid waste landfills in the province of Madrid (Spain) have revealed the presence of elevated levels of heavy metals (Pastor and Hernández, 2012).

\section{Toxicity to Lemna minor and Daphnia magna}

The relative growth rate of $L$. minor during the whole 7-day exposure period was significantly affected by the leachate (ANOVA, $F=459.41, p<0.001$ ) (Figure 2A). The breakdown of all colonies of $L$. minor was observed after their exposure to the solutions containing more than $12.5 \%$ of the leachate. The exposure to the lowest (3.125\%) leachate concentration in the medium led to a decrease of the growth rate by $34.07 \%$ in comparison with the control plants $(\mathrm{p}<0.05)$. The calculated $\mathrm{EC}_{50}$, effective concentration resulting in the relative growth rate reduction by $50 \%$, was $4.7 \%$ for Panevežys MSW leachate, i.e., TU 21.78. The results indicate that the landfill leachate could be considered as highly acute toxic for the growth of aquatic plants.

L. minor grown in Aulamas stream water produced fewer new fronds than $L$. minor grown in the control medium. The relative growth rate of $L$. minor in Aulamas stream water was by $45.5-52.96 \%$ lower than that of the control plants $(p<0.05)$ (Figure 2B). The relative growth rate of $L$. minor exposed to Aulamas surface water downstream the landfill (HP1 site) was by $15.86 \%$ higher than that exposed to Aulamas surface water upstream the landfill (HP2 site); however, the difference was not statistically significant ( $U$-test, $p=0.38$ ). The higher new frond production in HP1 treatment could be explained by higher nutrient concentrations downstream the landfill (Table 1). The study indicates that the landfill affects the surface water quality, which may lead to reduced aquatic plant growth. Several studies have observed that even groundwater collected near a landfill might be phytotoxic and reduce algae growth (Baun
Fig. 2

Relative growth rate of $L$. minor exposed to leachate and surface water for 7 days

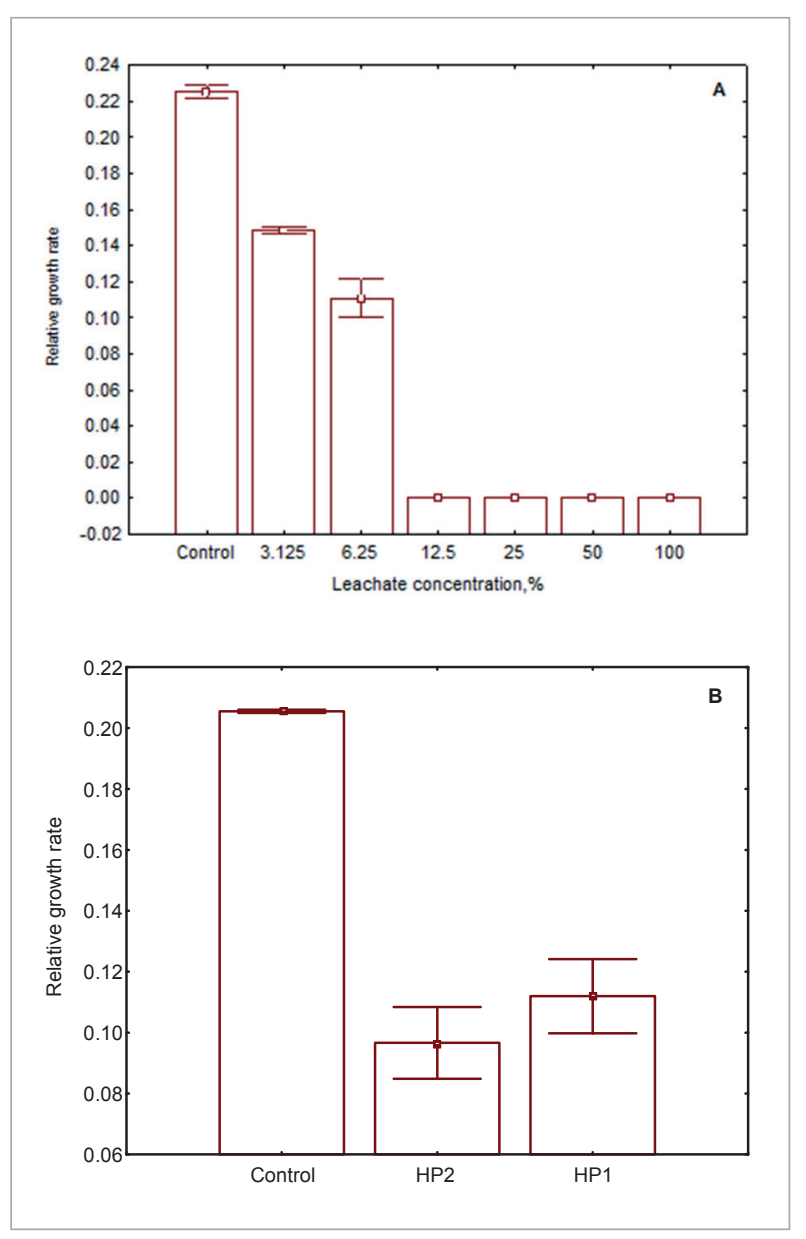

et al., 2000). Our results correspond well with those obtained in other studies indicating that leachate concentrations higher than $10 \%$ exhibit extremely high toxicity to the growth of $L$. minor (Clément and Bouvet, 1993, Devare and Bahadir, 1994). Untreated landfill leachate has been shown to reduce the growth rate, frond area, chlorophyll content and fluorescence of 4 strains of L. minor (Mackenzie et al., 2003).

Since the leachate concentrations higher than $12.5 \%$ induced the death of $L$. minor colonies, the dry weight of L. minor was analysed only for $3.125 \%$ and $6.25 \%$ treatments (Figure 3A). Both treatments with low leachate concentrations (3.125\% and 6.25\%) resulted in higher dry weight of plants in comparison with the control 
ones. The stimulatory effect was more pronounced in the treatment with the lowest concentration, which may be due to a high content of nutrients. This stimulatory effect could be explained by a high content of nutrients in the diluted leachate (Table 1). The second possible explanation for higher biomass in the low concentrations of the leachate could be that these colonies produced very few new fronds (Figure 2A), but they were of higher biomass. The stimulatory effects of low leachate or wastewater concentrations on the growth of plants have been recorded in several studies (Clément and Bouvet, 1993, Žaltauskaitè and Vaisiūnaitè, 2010, Žaltauskaitè and Čypaitè, 2008, Žaltauskaitè et al., 2014). This stimulation effect could be explained by sufficiently high concentrations of nutrients and relatively low concentrations of other toxic substances.

Fig. 3

Dry weight of $L$. minor exposed to leachate and surface water for 7 days

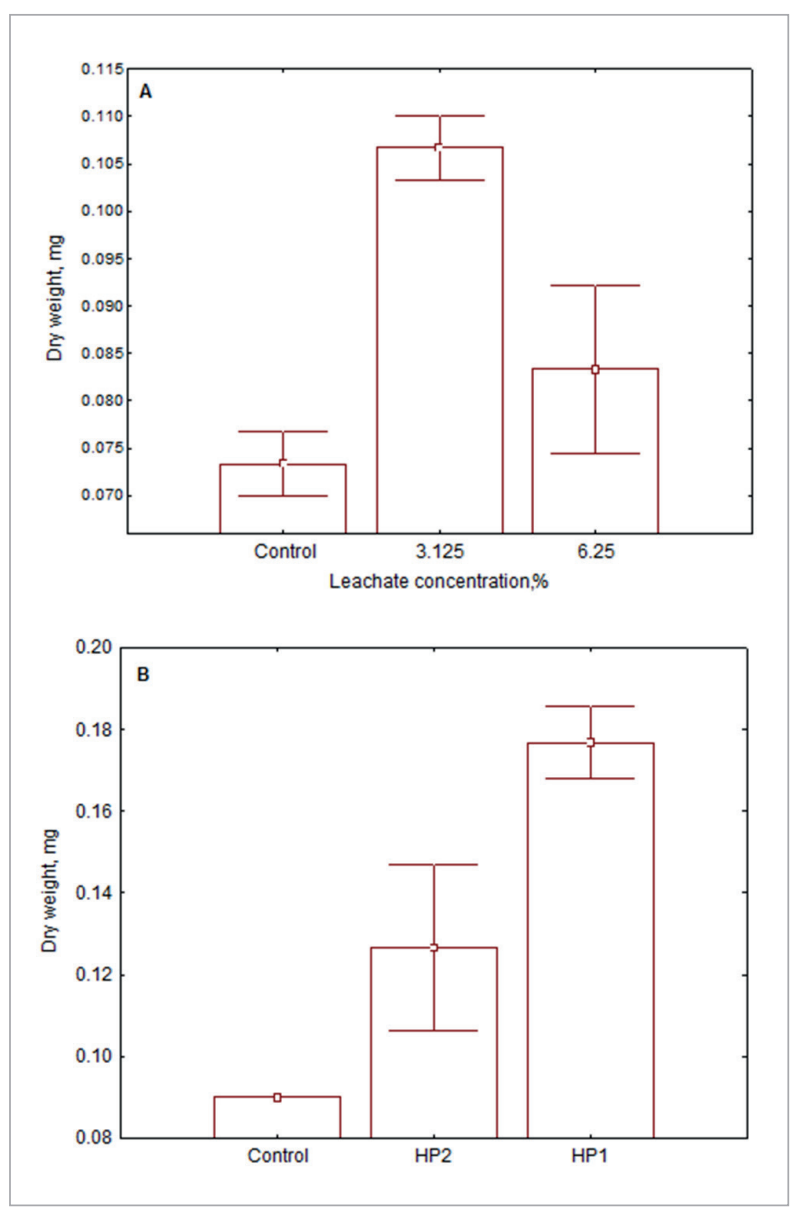

The similar stimulatory effect on the biomass growth was also observed in the treatment with Aulamas stream water. The dry weight of $L$. minor exposed to the surface water collected upstream the landfill was by $40.22 \%$ higher than the dry weight in the control. L. minor plants exposed to the surface water collected downstream the landfill were almost twofold higher than the control plants $(p<0.05)$.

The leachate had a very significant effect on $D$. magna (ANOVA, F24 $=91.50$, F48 $=122.00, p<0.001$ ) survival (Figure 4A). Only the lowest tested leachate concentration (3.125\%) produced no mortality. The $6.25 \%$ and $12.5 \%$ treatments led to the death of more than $20 \%$ of D. magna after $24 \mathrm{~h}$ of exposure, and the toxicity had increased after one more day of exposure, i.e., the mortality reached $40 \%$ and $100 \%$, respectively. An increase

Fig. 4

Mortality of $D$. magna exposed to leachate $(A)$ and surface water (B) for $24 \mathrm{~h}$ and $48 \mathrm{~h}$
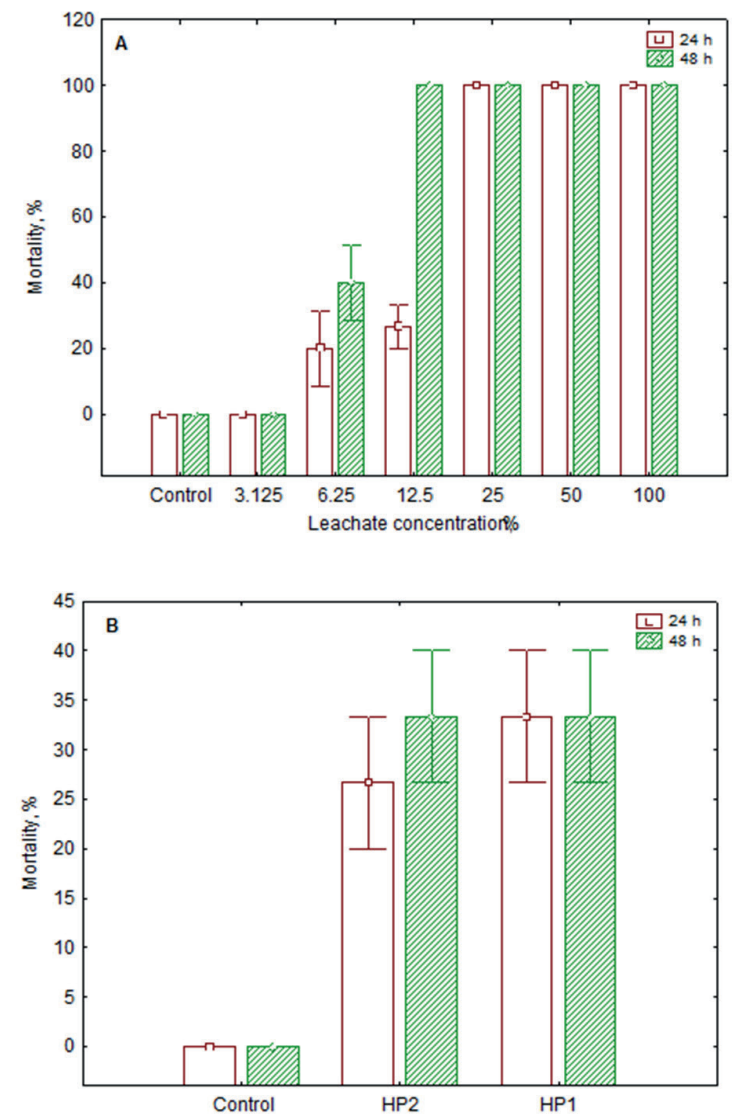
in the leachate concentration from $12.5 \%$ to $25 \%$ in solution resulted in a sharp increase in mortality, which reached $100 \%$. The results of logistic regression show that the risk of death of $D$. magna increases with the concentration of the leachate in the test solution (24h: $\left.x^{2}=104.65,48 \mathrm{~h}: x^{2}=118.34 ; p<0.001\right)$. The calculated $\mathrm{LC}_{50}$ value was $11.93 \%$ for $24 \mathrm{~h}$ and $6.92 \%$ for $48 \mathrm{~h}$. The results indicate that the leachate toxicity increased with the time of exposure. The calculated $\mathrm{LC}_{50}$ corresponds to $8.38 \mathrm{TU}$ and $14.45 \mathrm{TU}$ for $24 \mathrm{~h}$ and $48 \mathrm{~h}$, respectively. Based on the calculated toxic units, Panevezžys MSW landfill leachate is classified as highly acute toxic to $D$. magna. The determined TU using the $D$. magna immobilisation test were in accordance with the results of a study in France when 27 landfill leachates were studied (Clément et al., 1997). High acute toxicity of landfill leachates to aquatic micro-invertebrates, such as Daphnia magna and Thamnocephalus platyurus, has been recorded in previous studies (Matejczyk et al., 2014, Melnyk et al., 2014).

Aulamas stream water had a significant effect on $D$. magna survival (ANOVA, F > 10.5, $p<0.05$ ) (Figure 4B). The stream water taken upstream the landfill had no acute toxicity for $D$. magna after $24 \mathrm{~h}(<0.4 \mathrm{TU})$, but after $48 \mathrm{~h}$ it exhibited slight acute toxicity to $D$. magna. The mortality of $D$. magna exposed to Aulamas stream water downstream the landfill reached $33.33 \%$, which corresponds to the slight acute toxicity class. Melnyk et al. (2014) have tested the stream water collected upstream and downstream Gdansk landfill and observed that stream water collected downstream the landfill exhibited high toxicity to Thamnocephalus platyurus and Sorghum saccharatum. Moreover, high T. platyurus mortality was observed in the samples with low values of total organic carbon (TOC), the parameter of routine monitoring indicating that physicochemical analysis is insufficient to assess the ecological status of surface water bodies.

\section{References}

Baun A., Jensen S.D., Bjerg P.L., Christensen T.H. and Nyholm N. (2000) Toxicity of organic chemical pollution in groundwater downgradient of a landfill (Grindsted, Denmark). Environmental Science and Technology 34:1647-1652. https://doi.org/10.1021/es9902524
D. magna was more sensitive to the leachate and the surface water than Lemna minor. Higher sensitivity of micro-invertebrates to the leachate compared with the sensitivity of primary producers (plants or algae) has been observed in several previous studies (Tsarpali et al., 2012).

\section{Conclusions}

Chemical analysis conducted on the soils and the surface water around the closed landfill showed that nutrients and heavy metals may be present in relatively high concentrations even after the closure of the landfill. It indicates that survey and monitoring of the closed landfill is of particulate concern. The study revealed that leachate might be classified as highly acute toxic to aquatic plants. The leachate severely inhibited biomass and new frond production of Lemna minor. Surface water flowing through the landfill area inhibited the growth rate of Lemna minor, though a slight stimulation of biomass due to relatively high concentrations of nutrients was observed. It can be presumed that high concentrations of nutrients in water may mask the effects of other toxicants. Daphnia magna was extremely sensitive to the leachate and surface water. The obtained results indicate that the leachate could be classified as highly acute toxic. In summary of the results of chemical analysis and bioassays, it could be pointed out that the closed landfill remains a serious source of permanent pollution and might affect the biota in the surroundings of the landfill.

\section{Acknowledgements}

The authors' report was presented in the $10^{\text {th }}$ International Scientific Conference The Vital Nature Sign 2016.

Calace N., Massimiani A., Petronio B.M. and Pietroletti M. (2001) Municipal landfill leachate-soil interactions: a kinetic approach. Chemosphere 44:1025-1031. https://doi. org/10.1016/S0045-6535(00)00372-6 
Česonienè L. and Lukenskienè R. (2006) Lapių landfill impact on the Marilès stream water pollution with nitrogen compounds. In The proceedings of International Scientificpractice Conference Human and Nature Safety. Akademija, Kaunas district, June 1-3, 2006, pp. 131-133. (in Lithuanian)

Clément B. and Bouvet Y. (1993) Assessment of landfill leachate toxicity using the duckweed Lemna minor. The Science of the Total Environment 134(S2): 1179-1190. https://doi. org/10.1016/S0048-9697(05)80123-8

Clément B., Colin J.R. and LE Dû-Delepierre A. (1997) Estimation of the hazard of landfills through toxicity testing of leachates. 2. Comparison of physic-chemical characteristics of landfill leachates with their toxicity determined with a battery of tests. Chemosphere 35: 2783-2796.

Council Directive 1999/31/EC, of 26 April 1999, on the landfill waste.

Devare M. and Bahadir M. (1994) Biological monitoring of landfill leachate using plants and luminescent bacteria. Chemosphere 28: 261-271. https://doi.org/10.1016/00456535(94)90123-6

Eggen T., Moeder M. and Arukwe A. (2010) Municipal landfill leachates $L$ a significant source for new and emerging pollutants. Science of the Total Environment 408: 5147-5157. https://doi.org/10.1016/j.scitotenv.2010.07.049

Eurostat 2014. http://epp.eurostat.ec.europa.eu/portal/page/ portal/statistics/search_database. Accessed 12 September, 2016.

Hernández A.J., Adarve Alcazar M.J. and Pastor J. (1998) Some impacts of urban waste landfills on Mediterranean soils. Land Degradation and Development 9: 21-33. https:// doi.org/10.1002/(SICI)1099-145X(199801/02)9:1<21::AIDLDR269>3.0.CO;2-R

ISO/DIS 20079. (2004) Water quality- determination of the toxic effect of water constituents and waste water to duckweed (Lemna minor) - Duckweed growth inhibition test.

Jaskelevičius B. and Lynikienè V. (2009) Investigation on influence of Lapès landfill leachate on ground and surface water pollution with heavy metals. Journal of Environmental Engineering and Landscape Management 17: 131-139.https://doi. org/10.3846/1648-6897.2009.17.131-139

Juodkazis \& Urbanavičiūtė 2002; JUODKAZIS, V., URBANAVIČIŪTĖ, R. Organic matter spread in groundwater under impact of municipal waste dumps. Geologija, 2002, Vol. 40, pp. 32-45. (in Lithuanian)Vilnius

Kjeldsen P., Barlaz M.A., Rooker A.P. Baun A., Ledin A. and Christensen T.H. (2002) Present and long-term composition of MSW landfill leachate: a review. Critical Reviews in Environ- mental Science and Technology 32(4): 297-336. https://doi. org/10.1080/10643380290813462

Laner D., Crest M., Scharff H., Morris J.W.F. and Barlaz M.A. (2012) A review of approaches for the long-term management of municipal solid waste landfills. Waste Management 32: 498-512. https://doi.org/10.1016/j.wasman.2011.11.010

MacDonald N.W., Rediske R.R. and Scull B.T. (2008) Landfill cover soil, soil solution, and vegetation responses to municipal landfill leachate applications. Journal of Environmental Quality 37: 1974-1985. https://doi.org/10.2134/jeq2007.0637

Mackenzie S. M., Waite S., Metcalfe D. J. and Joyce C. B. (2003) Landfill leachate ecotoxicity experiments using Lemna minor. Water, Air, and Soil Pollution Focus 3: 171-179. https://doi.org/10.1023/A:1023973516564

Matejczyk M., Płaza G.A., Nałęcz-Jawecki G., Ulfig K. and Markowska-Szczupa A. (2014) Estimation of the environment risk posed by landfill using chemical, microbiological and ecotoxicological testing of leachates. Chemosphere 82: 1017-1023. https://doi.org/10.1016/j.chemosphere.2010.10.066

Melnyk A., Kuklinska K., Wolska L. and Namiesnik J. (2014) Chemical pollution and toxicity of water samples from stream receiving leachate from controlled municipal solid waste (MSW) landfill. Environmental Research 135: 253-261. https:// doi.org/10.1016/j.envres.2014.09.010

OECD 2004. Guideline for the testing of chemicals (221). Lemna sp. Growth inhibition test.

Order for approval the requirements for chemicals contaminated land management, D1-230. (2008) Environmental Ministry of Lithuania (2008-08-30)

Order of the surface water for freshwater fish living and breeding protection requirements, D1-633 (2005) Environmental Ministry of Lithuania, (2005-12-21)

Pablos M.V., Martini F., Fernández C., Babín M.M., Herraez I., Miranda J., Martínez J., Carbonell G., San-Segundo L., García-Hortigüela P. and Tarazona J.V. (2011) Correlation between physicochemical and ecotoxicological approaches to estimate landfill leachates toxicity. Waste management 31: 1841-1847. https://doi.org/10.1016/j.wasman.2011.03.022

Pastor J. and Hernández A.J. (2012) Heavy metals, salts and organic residues in oil solid urban waste landfill and surface waters in their discharge areas: determinants for restoring their impact. Journal of Environmental Management 95: S42-S49. https://doi.org/10.1016/j.jenvman.2011.06.048

Persoone G., Marsalek B., Blinova I., Törökne A., Zarina D., Manusadžianas L., Nalecz-Jawecki G., Tofan L., Stepanova N., Tothova L. and Kolar B. (2003) A practical and user-friendly toxicity classification system with Microbiotests for natural 
waters and wastewaters. Environmental Toxicology 18: 395402. https://doi.org/10.1002/tox.10141

Sizirici B., Tansel B. and Kumar V. (2011) Knowledge based ranking algorithm for comparative assessment of post-closure care needs of closed landfills. Waste management 31 : 1232-1238. https://doi.org/10.1016/j.wasman.2011.01.014

Standards for effluent quality (LAND-10-96) (1996). Environmental Ministry of Lithuania, Vilnius, p. 12.

Svecevičius G., N. Kazlauskienè N., Slučkaitè A. and Makaras T. (2013) Toxicological assessment of the effects of closed landfill on neighboring hydroecosystem. In: Proceedings of the 4th International Conference on Environmental Management, Engineering, Planning and Economics (CEMEPE) and SECOTOX Conference. Mykonos, Greece, June 24-28, 2013, pp. 799-804.

Svensson B.-M., Mathiasson L., Mårtensson L. and Bergström S. (2005) Artemia salina as test organism for assessment of acute toxicity of leachate water from landfills. Environmental Monitoring and Assessment 102: 309-321. https://doi. org/10.1007/s10661-005-6029-z

Thomas D.J.L., Tyrrel S.F., Smith R. and Farrow S. (2009) Bioassays for the evaluation of landfill leachate toxicity. Journal of Toxicology and Environmental Health Part B, 12: 83-105. https://doi.org/10.1080/10937400802545292

Tsarpali V., Kamilari M. and Dailianis S. (2012) Seasonal alterations of landfill leachate composition and toxic potency in semi-arid regions. Journal of Hazardous Materials 233-234: 163-171. https://doi.org/10.1016/j.jhazmat.2012.07.007

Ward M.L., Bitton G., Townsend T. and Booth M. (2002) Determining toxicity of leachates from Florida municipal solid waste landfills using a battery-of-tests approach. Environmental Toxicology 17: 258-266. https://doi.org/10.1002/tox.10053

Žaltauskaitè J. and Čypaitè A. (2008) Assessment of landfill leachate toxicity using higher plants. Environmental Research, Engineering and Management 4(46): 42-47.

Žaltauskaitè J. and Vaisiūnaitè R. (2010) Evaluation of municipal effluent toxicity using higher plants and invertebrates. Environmental Research, Engineering and management 3(53): 17-23.

Žaltauskaitè J., Sujetovienè G., Čypaitè A. and Aužbikavičiūtè A. (2014) Lemna minor as a tool for wastewater toxicity assessment and pollutants removal agent. Environmental engineering: 9th international conference, 22-23 May 2014, Vilnius, Lithuania: selected papers. p. 1-7. https://doi.org/10.3846/ enviro.2014.104

\section{Toksikologinis uždaryto municipalinių atliekų sąvartyno poveikio aplinkai vertinimas}

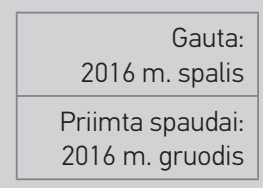

\section{Jūratė Žaltauskaitè, Iveta Vaitonytè}

Vytauto Didžiojo Universitetas, Gamtos mokslų fakultetas, Aplinkotyros katedra, Kaunas, Lietuva

Didelis municipalinių kietujų atliekų sąvartynų skaičius Lietuvoje kelia rimtą grėsmę dirvožemio, paviršinio ir požeminio vandens kokybei. Uždaryto Panevéžio buitiniu atliekų sąvartyno filtrato poveikis dirvožemiui ir paviršiniam vandeniui ir jo toksiškumas buvo vertinamas fizikocheminiais metodais bei biotestais. Sąvartyni filtratas tai jevairių organinių ir neorganinių junginių mišinys. Sąvartyno filtrato toksiškumas buvo vertinamas taikant biotestus su vandens augalais (Lemna minor L.) ir mikrobestuburiais (Daphnia magna). Sąvartyno filtratas buvo toksiškas $D$. magna, neigiamai veike L. minor augimo greiti ir biomasės prieaugi. Didelis filtrato toksiškumas sietinas su aukšta amonio jonų ir sunkiųju metalų koncentracija. 